\title{
Legacy of the Truman Doctrine on Turkish-American Relations: A Political Economy Perspective
}

Emrullah Can KILIÇ (https://orcid.org/0000-0002-0820-736X), Presidency of the Republic of Turkey, Turkey; ecan.kilic@tccb.gov.tr

Itur ÖZER-IMER (https://orcid.org/0000-0002-7779-1440), Hacettepe University, Turkey; itirozer@gmail.com

\section{Türk-Amerikan İlişkilerinde Truman Doktrini’nin Mirası: Bir Ekonomi Politik Perspektifi}

\begin{abstract}
This paper aims to scrutinise the need for a new path in Turkish-American relations from a political economy perspective with a strong emphasis on the legacy of the Truman Doctrine. The paper is based on the assumption that Turkish-American relations need a renewed policy paradigm and argues that matters of controversy are likely to prevail unless such a paradigm is found on a political economy basis. Even though the task of reviving Turkish-American relations via tools of political economy is not an easy one, there are several steps to be taken, which can pave the way to this goal.

Keywords

: Turkish-American Relations, Truman Doctrine, Political Economy.

JEL Classification Codes : F50, F52, F59.

$\ddot{\mathbf{O z}}$

Bu çalışma, Türk-Amerikan ilişkilerinde yeni bir yöne olan ihtiyacı Truman Doktrininin mirasına güçlü bir vurgu yaparak ekonomi politik perspektifinden incelemeyi amaçlamaktadır. Çalışma, Türk-Amerikan ilişkilerinin yenilenmiş bir politika paradigmasına ihtiyaç duyduğu varsayımına dayanmakta ve böyle bir paradigma ekonomi politik temeline dayandırılmadığı müddetçe, anlaşmazlıkların büyük olasılıkla devam edeceğini öne sürmektedir. Türk-Amerikan ilişkilerine ekonomi politik araçlarıyla canlılık kazandırmak kolay olmamakla birlikte, bu hedefe giden yolda atılabilecek belirli adımlar vardır.
\end{abstract}

Anahtar Sözcükler $\quad$ : Türk-Amerikan İlişkileri, Truman Doktrini, Ekonomi Politik. 


\section{Introduction}

Dating back to 1800 , Turkish-American relations can easily be classified as longtermed. Although bilateral relations were highly limited at the time of the Ottoman Empire, the predecessor of modern-day Turkey, the two countries were brought closer by historical milestones, namely wars. A mutually-beneficial alliance has become the main determinant of relations between Turkey and the United States.

Turkey has had shifting foreign policy patterns towards the United States after the Second World War II. In the aftermath of the war, Turkey has faced serious security problems rather than the economic ones. It was this search for security that resulted in Turkey's involvement in the Western bloc within the scope of the Truman Doctrine in 1947, which was supported by the Marshall Plan in 1948. Turkey finally became a member of the North Atlantic Treaty Organisation (NATO) in 1952. During the Cold War period, Turkey had been a reliable ally of the United States and a NATO member. Therefore, it is possible to put forward that security defined Turkish-American relations right from the start (Ozel, 2011: 56).

The end of the Cold War and the speeding up of the globalisation process fundamentally transformed the nature of Turkey's relations with the United States. The traditional patterns were no longer sufficient in guiding the bilateral relations (Lesser, 2006: 92). The recent times, especially, witnesses a great deal of discomfort in Turkish-American relations, which raises apprehension on both Turkish and American sides. It can be claimed that the current controversies in Turkish-American relations are more wide-ranging in scope than the previous ones as they comprise numerous issues, spheres, and nations. These controversies are also reflected in the opinion of the Turkish people. According to Pew Research Center survey in 2017, only $18 \%$ of the Turks have a favourable view of the United States. This is lower than the $30 \%$ favourable opinion in $2002^{1}$. In the meantime, the favourable view of Russia among the Turkish people seem to have increased to $32 \%$ for the same year from $17 \%$ in $2007^{2}$. This increase in favourable opinion regarding Russia is in accordance with the fact that Turkey seeks to be more active in regions such as the Middle East.

The aim of this study is not to provide a complete history of relations between Turkey and the United States, yet, a brief retrospect will be provided in the following section, and some milestones will be touched upon in the subsequent sections. As a matter of fact, it is not possible to examine such a wide area in its all dimensions in a single study. This can be observed in the extensive literature and in studies, each dwelling on different aspects of Turkish-American relations.

$<$ https://www.pewresearch.org/global/database/indicator/1/country/TR>, 28.10.2019.

$<$ https://www.pewresearch.org/global/database/indicator/27/country/TR>, 28.10.2019. 
This article is based on the assumption that Turkish-American relations need a renewed policy paradigm and argues that matters of controversy are likely to prevail unless such a paradigm is found on a political economy basis. Such a paradigm is supposed to compromise expectations of both sides with post-Cold War realities. In approaching Turkish-American relations from a political economy perspective, this paper hopes to offer concrete, policy-relevant insights that will be of benefit to political leaders in Turkey and the United States, as well as academicians and policy makers.

\section{Retrospect}

In the $19^{\text {th }}$ century, relations with the other were not a matter of priority for either Turks or Americans. It was American naval presence in the Mediterranean that laid the foundation of Turkish-American relations. In the early 1800s, increased American trade and diplomatic activity in the Mediterranean gave momentum to relations. Commercial exchanges mostly consisted of Ottoman imports of petroleum products and arms. However, American interest in Turkey was highly limited despite missionaries and commercial interests. In the following decades, Turkey's orientation was mostly European, with Germany being the leading strategic ally (Larrabee \& Lesser, 2003: 160-1).

The eruption of the First World War (WWI) brought already limited contacts between the two countries to a halt. American declaration of war on Germany in 1917 inevitably led to the rupture of diplomatic relations between the Ottoman Empire and the United States, resulting in a decade-long break in relations. However, the ties between the two countries were revived after the foundation of the Republic of Turkey. Distinctive differences between the Ottoman Empire and the Young Republic were highly facilitative in the restoration of relations. The political and social reforms of the Turkish Republic such as secular construction of the state and replacement of the Arabic alphabet with Latin alphabet were indications of the country's Western orientation. This period of rapprochement also transformed the perception of "Turk" in Americans' mind (Yilmaz, 2006: 223-5).

Partly due to ongoing anti-Turkish propaganda by Armenians in America and partly due to lack of sound information about Turkey, the New Republic's reforms were met with scepticism by some Americans. However, these reforms prepared a favourable environment for Turkish-American relations to flourish. A variety of actors were part of the efforts for the restoration of relations between the two countries. The United States High Commissioner Admiral Mark Lambert Bristol or ambassadors such as Joseph C. Grew (1927-1932) and Charles H. Sherrill (1932-1933) paid considerable efforts for the improvement of relations (Trask, 1970: 41-44). On Turkish side, a very important figure of the independence war and nationalist writer Halide Edip Adıvar published works countering anti-Turk voices and described the Young Republic for Americans. Following remarks by Adivar clearly demonstrates the Turkish willingness to improve ties with the United States in that period;

"America has raised the standard of the man in the street as it has never been raised before. Every American, from the poorest paid shop girl to the millionaire, is 
undergoing a perpetual education from the cradle to the grave. An enormous number of scientific and educational organizations handle the child almost from the moment of its birth. An enormous number of organizations keep the American in the street in touch with what is going on in the world - at large intellectual, artistic, political, and economic." (Adıvar, 1930: 244).

In addition, reciprocal visits and contacts by business people, companies, particular organisations and leading figures were also the driving force of Turkish-American rapprochement at that time. Improvement in relations during inter-war years can be considered to have built the groundwork of Turkish-American relations after the WWII.

The WWII was a breakthrough for not only global political and economic order but also for Turkish-American relations. Unlike the WWI, Turkey adopted the principle of nonbelligerence in order to avoid being a part of the conflict and avoid occupation during the war. Even staying out of the war bore dramatic consequences for Turkey. Turkish economy, which was mostly based on agriculture, severely suffered from mobilisation of a large army. Notwithstanding the economic loss resulting from the war, Turkey survived the WWII, following a successful strategy of balance of power (Oran, 2011: 235-241).

Turkey's neutrality in the WWII did not exempt it from Soviet territorial claims on eastern provinces of Kars and Ardahan and demands for renewing the terms of the Montreux Convention which regulated the use of the Straits (Satterthwaite, 1972: 77). Soviets also stipulated that the 1925 Soviet-Turkish Treaty of Friendship and Neutrality could be renewed only when these demands were satisfied. Arguing the international nature of the Montreux Convention, Turkey ruled out negotiating the status of the Straits and surrendering any territory to the Soviet Union (as cited in Evered, 2010: 53).

The Soviet threat can be regarded as a key turning point for the political history of the modern Republic of Turkey. Turkey's strict rejection of the Soviet proposals and problems regarding the modernisation of its army led Turkey welcome the support of the Truman Doctrine. The Soviet threat not only paved the way for Turkey's Western alignment and membership to the NATO but also shaped the Cold War strategy of the United States.

\section{The Truman Doctrine}

Turkey was far from being able to counter alone the security threats from the Soviets in the aftermath of the WWII (Isyar, 2005: 22). "After the beginning of the Ottoman decline in the late seventeenth century, Turkey had always been compelled to look to one of the Great Powers to support her against Russia. Turkey had generally obtained this support either from Britain or Austria-Hungary or later from Germany, but mostly it came from Britain. Except during the Great War, which brought Britain and Turkey into two opposite camps, the traditional British policy was to support Turkey as a barrier against Russian expansion southwards. This was the case when the USSR sought to extend its political and territorial influence at the expense of Turkey in the immediate post-Second World War 
period" (Bilgin \& Morewood, 2004: 24 ). However after 1945, Britain was no longer in a position to provide economic and military support to Greece and Turkey. Therefore, by the late 1946, it became obvious that the United States was needed to assume the responsibility of confronting the Soviet pressure and protecting the interests of the western world following the waned British influence (Çalış, 1997: 76).

In February 1947, the British government communicated to the U.S that by April, Britain would terminate its military and economic support to Turkey, hoping that this would be assumed by the United States. Consequently, American evaluation of the situation demonstrated that unless the United States took over this responsibility, Turkey would face the risk of falling under the Soviet's sphere of influence. Aware of this unsavoury possibility, the U.S. President Harry Truman addressed the Congress on March 12, 1947 and underlined the utmost necessity of supporting Greece and Turkey (Satterthwaite, 1972: 74). The decision of the United States to assume this leadership role can be considered as the milestone in Turkey's relations with the West.

Following excerpts from Truman's speech, which laid the basis of the Truman Doctrine, before the Congress demonstrates the importance attached to Turkey and Greece in what would later become the Cold War strategy of the U.S.

"...The gravity of the situation which confronts the world today necessitates my appearance before a joint session of the Congress. The foreign policy and the national security of this country are involved. One aspect of the present situation, which I wish to present to you at this time for your consideration and decision, concerns Greece and Turkey.

...The future of Turkey as an independent and economically sound state is clearly no less important to the freedom-loving peoples of the world than the future of Greece. The circumstances in which Turkey finds itself today are considerably different from those of Greece. Turkey has been spared the disasters that have beset Greece. And during the war, the United States and Great Britain furnished Turkey with material aid. Nevertheless, Turkey now needs our support.

Since the war, Turkey has sought financial assistance from Great Britain and the United States for the purpose of effecting that modernization necessary for the maintenance of its national integrity. That integrity is essential to the preservation of order in the Middle East. The British government has informed us that, owing to its own difficulties can no longer extend financial or economic aid to Turkey.

...As in the case of Greece, if Turkey is to have the assistance it needs, the United States must supply it. We are the only country able to provide that help. I am fully aware of the broad implications involved if the United States extends assistance to Greece and Turkey..."

Many regarded Truman's speech as the universal declaration of the United States to incite geopolitical security via foreign economic policy (Evered, 2010: 50). As President Truman emphasised in his address to the Congress, there were "broad implications involved" 
for not only the U.S. but also Turkey and the world politics itself. The Truman Doctrine is not only a milestone in the Cold War but can also be viewed as the turning point in American foreign policy (Merrill, 2006: 37). Thereafter, the aim of development was institutionalised for all world leaders. This characterised the beginning of the relationship between foreign economic policy and security for the United States. This, in addition, constituted the Cold War origins of development (Evered, 2010: 51).

Truman Doctrine also proved to be a turning point for the Young Republic. Military and economic implications of the U.S. aid to Turkey within the framework of Truman Doctrine considerably shaped the country's trajectory on the global arena.

With the enactment of "Public Law 75", the U.S. Congress approved the aid to Turkey and Greece. Public Law 75 set forth supporting these countries via "rendering financial aid", "personnel", "military services", and "instruction and training". According to Public Law 75, Greece and Turkey were entitled up to 400 million U.S. dollars for economic and military purposes.

By 1947, Turkey had a considerably large army which had to be mobilised during the WWII despite the neutrality of the county. Notwithstanding its largesse, Turkish army's capabilities were obsolete and it was ill-equipped. In this regard, American military aid played a significant role in modernisation and re-organisation of the army. Especially, the Turkish Air Force (TAF) was in a dire situation at the time. The TAF's inventory consisted of uncompetitive aircrafts and there was lack of adequate advanced training. Besides, TAF suffered shortage of ammunition and spare parts. To strengthen the TAF's battle capabilities, the U.S. provided aircrafts, aircrew training, ammunition, supply and maintenance as well as airfield construction and air defence artillery. The TAF's communication network was also enhanced via radios, telephones and radars. In addition to material capacity of the military, the U.S. also contributed to institutional development and reorganisation of the Turkish military establishment. This close cooperation on military affairs paved the way for Turkey’s formal alliance with the West (Livingston, 1994).

Military assistance in Turkey had broader positive externalites for the Turkish economy. Due to military support, a transportation network was built throughout the country, which brought about considerable economic gains for the Turkish economy (Kindleberger, 1968: 375). From another perspective, construction of these roads as part of the military assistance program made it possible for Turkey to devote its resources for economic purposes. By the time the program was launched, there were almost no all-weather road in the country (Satterthwaite, 1972: 80-2).

In Merrill's (2006: 28) words, “Truman's prescription centred on a positive program of aid giving to allies, and an ambitious agenda for nation building. The ideology of development is traceable to the early nineteenth century, an age of nascent industrialisation and continental expansion. Truman era officials respected those traditions, but drew on Keynesian theory to unleash the power of public financing and internationalise capitalism." 
As underlined by Evered (2010: 51), "conjoined nature of U.S. development and security policies" and "universal prescription of this twofold policy approach" is mostly neglected. The twofold approach of the Truman Doctrine projected a structure for not only international security but also development. It would be proper to claim that although it is generally neglected in academic studies in this field, it was the Truman Doctrine that introduced development as a universal objective (Evered, 2010: 62).

Employing economic tools of statecraft for security purposes was the course of action that Americans adopted in the Cold War until the war in Korea. Economic bricks of Truman Doctrine's containment wall also laid the ground for the Marshall Plan which foresaw economic rehabilitation of Western Europe. As Kindleberger states: "In the Marshall Plan, the economics profession got an opportunity to spend $\$ 17$ billion to test a theory about the relationships between economic dislocation and political behaviour. This experiment, too, was a success" (Kindleberger, 1968: 382).

According to Pollard (1985: 272-289), "the Truman presidency was probably more successful than any other post-war administration in planning and executing foreign economic policy". Truman administration employed economic power of its nation as the main tool in the U.S. security. However, the legacy of a barren understanding of the Truman doctrine constitutes a confining framework which reduces bilateral relations to a securitydominated approach. The need for a new path in Turkish-American relations has been voiced by many writers. This paper approaches to this need from a political economy perspective with a strong emphasis on the legacy of Truman Doctrine thinking. Truman Doctrine was a well-tailored response to potential expansion of the communist wave. The mind-set of the doctrine was a genius conjunction of security concerns and economic planning. In this regard, military aids were complemented by economic assistance, giving way to a strong amalgamation of "geo-politics" and "geo-economics". The aptly-use of economic instruments for the sake of geopolitical goals brought about the success of the Doctrine ${ }^{3}$.

\section{Turkey's Intrinsic Value}

It was Turkey's search for a safe haven in the face of security threats from the Soviet Union that eventually led to Turkey's alliance with the West. In the formation of this alliance which was formalised with membership of Turkey in the NATO, Turkey's "strategic importance" was the key point for the U.S. (Atmaca, 2014: 19). Regarded as a pivotal country for the peace and security of the Western World, Turkey was included in the Truman

\footnotetext{
Some argue that the Truman Doctrine can be regarded as the meddling of the U.S. in both the independence and internal matters of Turkey (Ünlü-Bilgiç, 2015: 256-257). It is also claimed that "military and economic external dependence was founded by the Truman Doctrine” (Kalyon, 2010: 21; Koç \& Koç, 2017: 103). For example, Turkey could use the military equipment provided by the U.S. on the condition that a foreign invasion took place. The following years witnessed the same condition imposed on the U.S. military assistance to Turkey, hence, it was claimed that it made Turkey politically and militarily dependent on the U.S. (Erhan \& Siviş, 2017: 93). Likewise, some attribute Turkey's loss of ability to independently design and perform defence policies to the Truman Doctrine (Kurç, 2010: 262).
} 
Doctrine, playing a historical role within the framework of the Cold War. The output of the Doctrine pointed to a win-win scenario for both parties; namely Turkey and the U.S. While the former significantly benefited from military and economic aid programs, the latter successfully carried out the Cold War strategy. However the end of the Cold War created new challenges for Turkey. With the disappearance of the common threat, Turkey ended up facing the unpleasant likelihood of losing its "strategic importance".

On the other hand, "its strategic importance" might also constitute a trap for Turkey. Especially after the end of the Cold War, Turkey sought to underline its strategic importance in order to strengthen its position in the Western Camp. With regard to Turkish-American relations, a similar dilemma faces Turkey. Therefore, the overemphasis on the concept of "strategic importance" points out to lack of "intrinsic value" in bilateral relations. In other words, the U.S. attaches an "instrumental value" to its relations with Turkey. This approach is most visible in cases of American military interventions in Iraq. Assigning the role of "stepping stone" to Turkey is likely to relegate Turkish-American relations from "strategic" to "tactical level".

In several occasions, Turkey sought to highlight its commitment to the Western alliance. For instance, by sending troops to the Korean War in 1950 and volunteering to host Jupiter missiles during the Cuban Missile Crisis in 1962, Turkey made efforts to underline and maintain its Western orientation. However, limiting Turkey's participation in the alliance to instrumental expectations is likely to tip the balance of win-win cooperation against Turkey's national interests. The Gulf War (1990-1991) and 2003 Invasion of Iraq offer adequate cases to analyse in this respect.

Following the invasion of Kuwait by Saddam Hussein's Iraq in 1990, the U.S. and Western nations took action to intervene. In response to Iraqi defiance to United Nations Security Council resolutions demanding the withdrawal of Iraqi troops, U.S.-led air strikes began against Iraqi army. Also known as "Operation Desert Storm”, the military intervention resulted in a quick victory (Al-Marashi, 2018). On the other hand, the implications of the war was much more elaborate for Turkey. In the first place, Turkey sought to capitalise the Gulf War with a view to substantiate its geostrategic importance in the face of its chief ally, the U.S. Particularly, in the post-Cold War period, Turkey needed to reassert its commitment to and significance in this alliance. In this regard, Turkey agreed to deploy forces along its Iraqi border in order to divert Iraqi forces from Kuwait border. In addition, Turkish air space was open to the U.S. Furthermore, the Gulf War inflicted enormous economic loss on the Turkish economy. While cutting the oil supply from Iraqi pipelines, the economy suffered a loss of 1.2 billion $\$$ by the end of the war (Kösebalaban, 2011: 123). Given that the war made hundreds of thousands of Iraqi Kurds take refuge in Turkey, the overall costs for Turkey can be considered much higher.

Upon urging from the U.S., Turkey made considerable contribution to the coalition effort in the Gulf War. However, Turkish expectations in the first place were replaced by disappointment and dissatisfaction (Larrabee \& Lesser, 2003: 166). The war dramatically 
affected the territorial integrity and military sovereignty of Iraq. Particularly the no-fly zone imposed over Kurdish region provided a safe haven for the PKK terrorist organisation, which created new challenges for Turkey's anti-terrorism struggle (Kösebalaban, 2011: 129).

The Truman Doctrine definitely played a historic role in Turkish-American relations and constructed a strong foundation on which bilateral relations can rise and diversify. However, matters of disagreement and diverging interests slowed the momentum of Turkish-American relations. In particular American military interventions in Iraq created dramatic consequences against Turkey's economic performance and its security. Therefore, Turkey's reaction was to seek for alternatives as an integral component of any sovereign state's foreign policy roadmap. Despite Turkey's commitment to Western alliance and Western institutions, the compass of national interest does not necessarily point to the West. On the other hand, Turkey's relations with Russia, Iran, Iraq and other countries in its hinterland are "intrinsically valuable". Constructed with fabrics of economy, historical links, culture, religion and politics, these relations prosper not as an alternative to those with the West but as complementary to them.

In Gelb's (2010) words, "GDP matters more than force" in today's world. Geoeconomic considerations should therefore complement geopolitics, if not replace it ${ }^{4}$. Bearing this pivotal consideration in mind, U.S. policy makers should define Turkey's intrinsic value as a partner in the Western alliance. Rather than determining Turkey's importance based on roles such as "bastion" or "buffer" assigned to it in American-fought wars, it is better to take into consideration the fact that Turkey is a representative of a strong statecraft and a long-lasting civilisation. Besides, Turkey is a strong candidate to become a regional hub of "development", "industrialisation", "institutional prowess" and "stability".

\section{Divergence of Interests and Choke Points in Turkish-American Relations}

Divergence of interests between Turkey and the U.S. became more visible in the years after the end of the Gulf War. Iraqi War in 2003 further deteriorated two countries' bilateral relations. On 1 March 2003, the government proposal to allow American forces to open a northern front on Turkish territory in the war failed to pass in Turkish Parliament. Also known as "1 March Crisis", the incident deepened the disagreements in TurkishAmerican relations. Lessons from the 1990-1991 Gulf War considerably shaped Turkey's position on 2003 Iraq War. Undergoing adverse effects of the Gulf War both economically and security-wise, Turkey pursued a more discreet policy in 2003. What is known as the "Hood Incident" came as another blow to Turkish-American relations in this period (Atmaca, 2011: 177). The arrest of 11 Turkish Commandos by U.S. soldiers added "loss of

4 The term geoeconomics has recently been introduced to the political economy literature, which means "the use of economic instruments to promote and defend national interests, and to produce beneficial geopolitical results; and the effects of other nations' economic actions on a country's geopolitical goals" (Blackwill \& Harris 2016: 9). 
trust" to diverging interest over Iraq (Müftüler-Bac, 2005: 61-81). On the other hand, these rifts between two countries led to rise of Anti-Americanism in Turkey . However, it should be noted that the Anti-Americanism in Turkey is not a direct opposition to "what the U.S. is or stands for in terms of civilisation" but to "what the U.S. does". While anti-Americanism results from historical reasons in other Mediterranean countries, the situation in Turkey is highly different (Grigoriadis, 2010: 54-55). To put it in other words, Anti-Americanism in Turkey can be classified as a "reactionary defiance" to American policies rather than a "principal antagonism" to American values, which suggests that there is no existential threat to the Turkish-American alliance.

As the important events and turning points mentioned so far demonstrate, in TurkishAmerican relations, the main motivation of Turkey was to assert its importance in TurkishAmerican alliance. However, it should be noted that Turkey has been resolute to keep it as a "win-win" alliance. For this purpose, Turkish-American relations should be reconfigured in accordance with post-Cold War realities. In other words, assigning merely "strategic importance" to Turkey and unilateral expectations would fail to promote Turkish-American relations.

To restate it in Lesser's (2006: 83) words, “Turkish-U.S. relations have been prisoners of a narrow concept of geopolitics". Assigning such relational roles as "bridge", "flank", "front" or "barrier" to Turkey will confine Turkish-American relations to a myopic vision.

In the post-Cold War period, the agenda of Turkish-American relations risk falling hostage to a number of negative subject matters which can be regarded as "choke points". Cyprus issue, successive military operations in Iraq, Armenian issue and Israel can be enumerated in this regard. The urgency of unshackling Turkish-American relations from aforementioned "choke points" is addressed by several writers. In this regard, emphasizing the need for "chartering a new way for Turkish-American relations", Stein (2011: 14) argues that "both countries have to work together to clearly enumerate each other's immediate interests, identify areas of convergence, and respect areas of disagreement". Gunter (2005: 122) mentions the call for a "new thinking on part of both partners" on issues such as Iraqi Kurds, Cyprus and Turkey's EU candidacy. According to Larrabee (2010), "revitalising the U.S.-Turkey relationship" is a key priority and efforts for this purpose should include the issues of "Northern Iraq and the PKK", "the Middle East", "Armenian issues", "Turkey's membership in the EU", "Cyprus" and "Defence cooperation". For Gordon and Taspinar (2008: 61-85), there are several important steps to be taken in order to put Turkish-American relations back on track. These are "promoting a grand bargain between Turkey and the Kurds", "support liberalism and democracy in Turkey", "promote historic compromise with Armenia", and "promote a political settlement in Cyprus".

Danford (2021: 6) refers to the current situation of the relationship between Turkey and the West as: "a hostile dance", however, Danford also adds that neither Turkey, nor the West can take the risk of an actual rift. The resilience of Turkey's relationship with the West, 
in general, and the U.S., specifically is touched upon by others as well (Beyoghlow, 2020; Buhari-Gulmez, 2020). It is believed that neither side would want to give an irreversable damage to their mutual relation (Beyoghlow, 2020: 71). However, if the Turkish-American relations were to worsen, the possible consequences of this rift gains importance. Flanagan \& Wilson (2021: 194-197) touch upon four possible scenarios with regard to Turkey's future: i)"difficult ally", ii) "resurgent democracy", iii) "strategic balancer", iv) "Eurasian power". The fourth scenario is the one, where tensions between Turkey and the West reaches its limit, Turkey formally leaves the Western alliance, NATO, and turns to countries in the Middle East and Eurasia (Flanagan \& Wilson, 2021: 197). If this is the case, the possible implications for Turkey would be: "i) Relations with the United States become distant, sometimes adversarial, ii) Routine alignment with Russia, Iran, and China to limit or offset U.S. influence, iii) Defense and military cooperation with the United States and NATO curtailed; access to bases denied. iv) Possible military incidents" (Flanagan \& Wilson, 2021: 198). It should also ben mentioned that in such a case, further economic sanctions from the U.S. would add to the problems of the already vulnerable Turkish economy.

Based on the above mentioned political, security and economic implications that would arise if the Turkish American relations are not improved, it can be argued that it would be more appropriate to take the necessary steps for the sake of improving Turkish-American relations rather than taking into consideration the long-term and waiting for the opportunities that may arise over time, and taking advantage of them in terms of improving and maintaining relations. The concrete reasons for this are the main negative consequences of the possible political, security and economic problems in case of a deterioration in TurkishAmerican relations ${ }^{5}$.

The emphasis that writers put on "choke points"; namely Cyprus and Armenian issues, relations with Kurds and the PKK is ultimately important. Policy makers in both countries should take required measures to make sure that these matters of controversy don't poison bilateral relations. However, there is a shortage of "positive matters of engagement" in Turkish-American relations, which is widely neglected in the literature. In the absence of a common enemy, the need for "common interests" becomes even more obvious. At this point, economic interdependence and a win-win cooperation on economic development might add a positive dimension to bilateral relations.

\section{Not Only Security but Also Economics Matters}

In the post-Cold War international order, security challenges still continue to occupy an important place on countries' agenda. On the other hand, issues such as economic growth, infrastructure, development, energy security, industrialisation and social welfare increasingly dominate domestic and foreign policy making. Besides, multipolar nature of the international system allows nations pursue multidirectional policies in order to achieve

5 The future of Turkish-American relations is a heavily discussed issue. See: Arlsan-Eralp et al. (2021), RAND Corporation (2021), Ülgen (2021) for further discussions. 
these goals. Therefore, Turkish-American relations need to focus on not only security but also economic matters. It was the dual nature of the Truman Doctrine that brought about its success and made a win-win cooperation possible. In this respect, remembering the economic success of it will help today's decision makers construct a cooperation based on positive matters of engagement. In the absence of a common threat, both countries are expected to focus on a positive agenda so that relations can prosper in a mutually beneficial way.

Since the turn of the $21^{\text {st }}$ century, Turkey has been implementing a multi-directional foreign policy in a pragmatic way in order to promote its economic growth and political clout in the region. In accordance with this approach, economic considerations led to a considerable rapprochement between Turkey and its neighbours such as Russia, Iraq and Iran. Particularly, Turkey's relations with the villain of the Cold War dramatically improved in the last two decades. While Turkish-Russian relations were mostly characterised as hostile throughout the history, economic pragmatism and improved trade have brought two countries ever closer. Complementary nature of two countries' economies and highly intertwined interests overs energy projects in the region made cooperation inevitable. In addition to increased trade volume and energy cooperation, a number of issues such as tourism, technology transfer and people-to-people interactions play significant role in this rapprochement. On the other hand, Turkey built mutually beneficial economic cooperation with Iran and Iraq. While Iraq has become one of Turkey's top export markets, energy trade with Iran significantly improved. Despite controversial matters such as regional rivalry, sectarian differences, water issues and security matters, the trilogy was able to overcome their differences for the sake of pragmatic expectations (Kılıç, 2017: 55-64).

With indispensable economic considerations in question for both countries, Turkey and Russia achieved an unprecedented improvement in bilateral relations in the period after 2000. That is, trade with Russia has been an important driving force behind the visible improvement in Turkish-Russian relations (Larrabee, 2010: 160). A great number of high level state visits have been conducted reciprocally. While trade and energy have been up on the agenda during these visits, trade volume between the two countries witnessed such a considerable increase that Turkish-Russian economic rapprochement matched political dialogue which was also propelled by economic pragmatism. A bilateral trade of approximately $\$ 4.5$ billion in 2000 increased to more than $\$ 22.3$ billion in 2020 , demonstrating the extent of the role of trade in Turkish-Russian cooperation in the last two decades. Trade volume in 2020 was accompanied by a trade deficit to Turkey's disadvantage with a great portion of Turkey's trade deficit with Russia being based on its energy imports from the Russian Federation. As an energy-dependent country, Turkey imported a total of 45.211,47 million $\mathrm{sm}^{3}$ of natural gas in 2019. Russia is the largest supplier of natural gas to Turkey, with the share of $33.61 \%$, which amounts to 15.196 million $\mathrm{sm}^{3}$ for the same year (EPDK, 2019). In addition to trade in goods, two countries' services trade also strengthens this mutual dependence. While Turkish and Russian products complement each other, Turkish services exports in tourism and construction fields constitutes a key component of interdependence. 
It is argued in the literature that economic cooperation is one of a number of major subjects on which Turkish-Iranian relations are based (Calabrese, 1998). To denote the decreasing importance of security-related issues straining relations between the two countries, Aras and Karakaya Polat (2008) uses concept of "de-securitisation", which refers to shifting from a constant state of alert into a state of pragmatic and strategic calculations, while Sinkaya (2012) describes Turkey's pragmatic approach to relations with Iran as "rationalisation of Turkish-Iranian relations". In line with Turkey's post-2000 foreign policy, bilateral trade between Turkey and Iran increased. Turkish-Iranian trade volume was slightly more than $\$ 1$ billion in 2000 , and it increased approximately to $\$ 2.5$ billion in the first 6 months of $2021^{6}$. It should be noted that Iran is the $3^{\text {rd }}$ natural gas supplier for Turkey with 7.736 million $\mathrm{sm}^{3}$ after Russia and Azerbiajan (EPDK, 2019).

Despite the fact that geographical proximity between Turkey and Iraq is of pivotal importance with regard to the volume of trade, Iraq was not among the top destinations for Turkish exports in the early 2000s. However, this has changed in the last two decades. Iraq was the $3^{\text {rd }}$ export partner of Turkey with 5.4\% share in 2019. This illustrates that Turkey maintains highly important trade links with Iraq. In Müftüler-Baç's (2014) words, Turkey has been using trade and foreign direct investment as foreign policy tools strengthening its engagement with Iraq, which refers to use of trade as a "means". On the other hand, in line with Turkey's growing economy which is dependent on exports, Turkey wants to enlarge its export markets in Iraq (Barkey, 2011), making the use of trade an "end" in this regard.

Turkey's growing activism in the Middle East, Africa and Central Asia and strengthening relations with non-western countries led to debates on Turkey's western orientation. It was alleged that the axis of Turkish foreign policy began to shift from the west to the east (Kutlay, 2011; Civan, Genç, Taser \& Atakul, 2013; Babacan, 2011; Öniş, 2011). However such allegations are considered to be exaggerations. Turkey's bid to benefit from emerging possibilities in its environment, especially its drive to make it to exclusive club of developed economies should be understood as sovereign nations' right to follow an independent foreign policy in search and wealth and power.

Positive externalities of economic interdependence and peace-inducing effects of trade links are widely appreciated. On the other hand, economic interests are capable of creating "common constituencies" for bilateral relations. Raising the stakes for all parties, economic interdependence also function as an "insurance mechanism" in case of crises. In this regard, Turkish-Russian relations provide a good case study to highlight these positive externalities from economic interdependence. Due to complementary nature of both economies and high level cooperation in mega projects, relations between Turkey and Russia have become considerably crisis-resistant. Two countries' prudent handling of " 2015 Jet Crisis" and restricted actions afterwards point to mitigating effects of positive matters of engagement.

6 See the data in Turkish Statistical Institute, <https://data.tuik.gov.tr>, 28.10.2019. 
The possibilities of creating "common constituencies" and "insurance mechanisms" for Turkey and the U.S. can be examined by scrutinising trade and investment between these countries.

Table: 1

Turkey's Imports by Country and Year, Share in Total Imports (\%)

\begin{tabular}{|c|c|c|c|c|c|c|c|c|c|c|}
\hline Rank & 1 & 2 & 3 & 4 & 5 & 6 & 7 & 8 & 9 & 10 \\
\hline Country/Year & Russian Federation & Germany & China & United States & Italy & France & India & Korea, Rep. & United Kingdom & Spain \\
\hline 1990 & .. & 15,7 & 1,1 & 10,2 & 7,7 & 6,0 & 0,4 & 1,4 & 4,5 & 1,5 \\
\hline 1991 & .. & 15,4 & 0,8 & 10,7 & 8,8 & 5,8 & 0,4 & 1,7 & 5,5 & 1,5 \\
\hline 1992 & 4,6 & 16,4 & 0,8 & 11,4 & 8,4 & 5,9 & 0,4 & 1,6 & 5,2 & 1,4 \\
\hline 1993 & 5,2 & 15,4 & 0,9 & 11,4 & 8,7 & 6,6 & 0,5 & 2,1 & 5,3 & 1,5 \\
\hline 1994 & 4,5 & 15,7 & 1,1 & 10,4 & 8,6 & 6,3 & 0,5 & 1,2 & 5,0 & 1,6 \\
\hline 1995 & 5,8 & 15,5 & 1,5 & 10,4 & 8,9 & 5,6 & 0,6 & 1,6 & 5,1 & 1,7 \\
\hline 1996 & 4,4 & 17,7 & 1,3 & 7,7 & 9,9 & 6,4 & 0,6 & 1,7 & 5,8 & 2,3 \\
\hline 1997 & 4,5 & 16,5 & 1,6 & 8,9 & 9,2 & 6,1 & 0,6 & 2,2 & 5,7 & 2,6 \\
\hline 1998 & 4,7 & 15,9 & 1,8 & 8,8 & 9,2 & 6,6 & 0,6 & 2,4 & 5,8 & 2,8 \\
\hline 1999 & 5,8 & 14,5 & 2,2 & 7,6 & 7,8 & 7,7 & 0,6 & 2,1 & 5,4 & 3,1 \\
\hline 2000 & 7,2 & 13,2 & 2,4 & 7,2 & 8,0 & 6,5 & 0,8 & 2,2 & 5,0 & 3,1 \\
\hline 2001 & 8,3 & 12,9 & 2,2 & 7,9 & 8,4 & 5,5 & 0,9 & 1,8 & 4,6 & 2,6 \\
\hline 2002 & 7,5 & 13,7 & 2,7 & 6,0 & 8,1 & 5,9 & 1,1 & 1,8 & 4,7 & 2,7 \\
\hline 2003 & 7,9 & 13,6 & 3,8 & 5,0 & 7,9 & 6,0 & 1,0 & 1,9 & 5,0 & 2,9 \\
\hline 2004 & 9,3 & 12,8 & 4,6 & 4,9 & 7,0 & 6,4 & 1,1 & 2,6 & 4,4 & 3,3 \\
\hline 2005 & 11,1 & 11,7 & 5,9 & 4,6 & 6,5 & 5,0 & 1,1 & 3,0 & 4,0 & 3,0 \\
\hline 2006 & 12,8 & 10,6 & 6,9 & 4,5 & 6,2 & 5,2 & 1,1 & 2,5 & 3,7 & 2,7 \\
\hline 2007 & 13,8 & 10,3 & 7,8 & 4,8 & 5,9 & 4,6 & 1,4 & 2,6 & 3,2 & 2,6 \\
\hline 2008 & 15,5 & 9,3 & 7,8 & 5,9 & 5,3 & 4,5 & 1,2 & 2,0 & 2,6 & 2,3 \\
\hline 2009 & 13,8 & 10,0 & 9,0 & 6,1 & 5,4 & 5,0 & 1,4 & 2,2 & 2,5 & 2,7 \\
\hline 2010 & 11,6 & 9,5 & 9,3 & 6,6 & 5,5 & 4,4 & 1,8 & 2,6 & 2,5 & 2,6 \\
\hline 2011 & 9,9 & 9,5 & 9,0 & 6,7 & 5,6 & 3,8 & 2,7 & 2,6 & 2,4 & 2,6 \\
\hline 2012 & 11,3 & 9,0 & 9,0 & 6,0 & 5,6 & 3,6 & 2,5 & 2,4 & 2,4 & 2,5 \\
\hline 2013 & 10,0 & 9,6 & 9,8 & 5,0 & 5,1 & 3,2 & 2,5 & 2,4 & 2,5 & 2,6 \\
\hline 2014 & 10,4 & 9,2 & 10,3 & 5,3 & 5,0 & 3,4 & 2,8 & 3,1 & 2,4 & 2,5 \\
\hline 2015 & 9,8 & 10,3 & 12,0 & 5,4 & 5,1 & 3,7 & 2,7 & 3,4 & 2,7 & 2,7 \\
\hline 2016 & 7,6 & 10,8 & 12,8 & 5,5 & 5,1 & 3,7 & 2,9 & 3,2 & 2,7 & 2,9 \\
\hline 2017 & 8,3 & 9,1 & 10,0 & 5,1 & 4,8 & 3,5 & 2,7 & 2,8 & 2,8 & 2,7 \\
\hline 2018 & 9,9 & 9,1 & 9,3 & 5,5 & 4,6 & 3,3 & 3,4 & 2,8 & 3,3 & 2,5 \\
\hline 2019 & 11,0 & 9,2 & 9,1 & 5,6 & 4,4 & 3,2 & 3,2 & 2,7 & 2,7 & 2,1 \\
\hline
\end{tabular}

Source: World Bank, $2021^{7}$.

As can be seen in Table 1., after the Russian Federation, Germany and China with $11 \%, 9,2 \%$ and 9,1\% shares, respectively in Turkey's imports, the United States has a share of $5,1 \%$ in 2019 , and this share was relatively stable in the past few years. However, compared to the 1990 and 2000 shares of $10,2 \%$ and 7,2\%, respectively, this share in 2019 is lower. Turkey's goods imports from the U.S. amounted to $\$ 11,9$ billion in 2019 , with a decrease from the value of $\$ 12.4$ billion in $2018^{8}$.

7 See: <https://wits.worldbank.org>, 28.10.2021.

8 See: <https://wits.worldbank.org>, 28.10.202. Table A.1 in the Appendix comprises Turkey's imports from the United States. 
Table: 2

Turkey's Exports by Country and Year, Share in Total Exports (\%)

\begin{tabular}{|c|c|c|c|c|c|c|c|c|c|c|}
\hline Rank & 1 & 2 & 3 & 4 & 5 & 6 & 7 & 8 & 9 & 10 \\
\hline Country/Year & Germany & United Kingdom & Iraq & Italy & United States & Spain & France & Netherlands & Israel & Russian Federation \\
\hline 1990 & 23,6 & 5,7 & 1,7 & 8,5 & 7,5 & 1,5 & 5,7 & 3,4 & $\begin{array}{ll}0,4 \\
\end{array}$ & .. \\
\hline 1991 & 25,1 & 5,0 & 0,9 & 7,1 & 6,7 & 1,8 & 5,1 & 3,5 & 0,6 & \\
\hline 1992 & 24,9 & 5,4 & 1,4 & 6,4 & 5,9 & 2,0 & 5,5 & 3,4 & 0,6 & 3,0 \\
\hline 1993 & 23,8 & 5,4 & 1,0 & 4,9 & 6,4 & 1,3 & 5,0 & 3,4 & 0,5 & 3,3 \\
\hline 1994 & 21,7 & 4,9 & 0,8 & 5,7 & 8,4 & 1,3 & 4,7 & 3,4 & 1,0 & 4,5 \\
\hline 1995 & 23,3 & 5,3 & 0,6 & 6,7 & 7,0 & 1,7 & 4,8 & 3,4 & 1,1 & 5,7 \\
\hline 1996 & 22,4 & 5,4 & 0,8 & 6,2 & $\mathbf{7 , 0}$ & 1,6 & 4,5 & 3,3 & 1,1 & 6,5 \\
\hline 1997 & 20,0 & 5,8 & 0,2 & 5,3 & 7,7 & 1,7 & 4,4 & 3,0 & 1,5 & 7,8 \\
\hline 1998 & 20,3 & 6,4 & 0,0 & 5,8 & 8,3 & 1,9 & 4,8 & 3,3 & 1,8 & 5,0 \\
\hline 1999 & 20,6 & 6,9 & ... & 6,3 & 9,2 & 2,9 & 5,9 & 3,5 & 2,2 & 2,2 \\
\hline 2000 & 18,8 & 7,4 & .. & 6,4 & 11,2 & 2,6 & 6,0 & 3,2 & 2,3 & 2,3 \\
\hline 2001 & 17,1 & 6,9 & .. & 7,5 & 10,0 & 3,0 & 6,0 & 2,8 & 2,6 & 2,9 \\
\hline 2002 & 16,3 & 8,4 & ... & 6,6 & 9,3 & 3,1 & 5,9 & 2,9 & 2,4 & 3,3 \\
\hline 2003 & 15,8 & 7,8 & 1,8 & 6,8 & 7,9 & 3,8 & 6,0 & 3,2 & 2,3 & 2,9 \\
\hline 2004 & 13,9 & 8,8 & 2,9 & 7,4 & 7,7 & 4,1 & 5,8 & 3,4 & 2,1 & 2,9 \\
\hline 2005 & 12,9 & 8,1 & 3,7 & 7,6 & 6,7 & 4,1 & 5,2 & 3,4 & 2,0 & 3,2 \\
\hline 2006 & 11,3 & 8,0 & 3,0 & 7,9 & 5,9 & 4,4 & 5,4 & 3,0 & 1,8 & 3,8 \\
\hline 2007 & 11,2 & 8,0 & 2,7 & 7,0 & 3,9 & 4,3 & 5,6 & 2,8 & 1,5 & 4,4 \\
\hline 2008 & 9,8 & 6,2 & 3,0 & 5,9 & 3,3 & 3,1 & 5,0 & 2,4 & 1,5 & 4,9 \\
\hline 2009 & 9,6 & 5,8 & 5,0 & 5,8 & 3,2 & 2,8 & 6,1 & 2,1 & 1,5 & 3,1 \\
\hline 2010 & 10,1 & 6,4 & 5,3 & 5,7 & 3,3 & 3,1 & 5,3 & 2,2 & 1,8 & 4,1 \\
\hline 2011 & 10,3 & 6,0 & 6,2 & 5,8 & 3,4 & 2,9 & 5,0 & 2,4 & 1,8 & 4,4 \\
\hline 2012 & 8,6 & 5,7 & 7,1 & 4,2 & 3,7 & 2,4 & 4,1 & 2,1 & 1,5 & 4,4 \\
\hline 2013 & 9,0 & 5,8 & 7,9 & 4,4 & 3,7 & 2,9 & 4,2 & 2,3 & 1,7 & 4,6 \\
\hline 2014 & 9,6 & 6,3 & 6,9 & 4,5 & 4,0 & 3,0 & 4,1 & 2,2 & 1,9 & 3,8 \\
\hline 2015 & 9,3 & 7,3 & 5,9 & 4,8 & 4,4 & 3,3 & 4,1 & 2,2 & 1,9 & 2,5 \\
\hline 2016 & 9,8 & 8,2 & 5,4 & 5,3 & 4,6 & 3,5 & 4,2 & 2,5 & 2,1 & 1,2 \\
\hline 2017 & 9,6 & 6,1 & 5,8 & 5,4 & 5,5 & 4,0 & 4,2 & 2,5 & 2,2 & 1,7 \\
\hline 2018 & 9,6 & 6,6 & 5,0 & 5,7 & 4,9 & 4,6 & 4,3 & 2,8 & 2,3 & 2,0 \\
\hline 2019 & 9,2 & 6,2 & 5,7 & 5,4 & 5,0 & 4,5 & 4,4 & 3,2 & 2,5 & 2,3 \\
\hline
\end{tabular}

Source: World Bank, $2021^{9}$.

According to Table 2., United States comes after Germany $(9,2 \%)$, United Kingdom $(6,2 \%)$, Iraq $(5,7 \%)$ and Italy $(5,4 \%)$, with a $5 \%$ share in Turkey's exports in 2019 . This share was again stable in recent years. However, compared to the shares of $7.5 \%$ and $11,2 \%$ in 1990 and 2000, respectively, this share in 2019 is lower. Turkey's goods exports to the U.S. was approximately $\$ 9$ billion in 2019 , with an increase from $\$ 8,3$ billion in $2018^{10} .^{11}$ With regard to trade, it can be stated that despite the increase in the overall trade between Turkey and the U.S. from $\$ 10,8$ billion in 2009 to approximately $\$ 20,9$ billion in 2019 , this volume of trade is still below its potential.

9 See the data in <https://wits.worldbank.org >, 28.10.2021.

10 See the data in <https://wits.worldbank.org >, 28.10.2021. Table A.2 in the Appendix comprises Turkey's exports to the United States. 


\section{Table: 3}

\section{Turkey's Foreign Direct Investment by Partner Country (Flow), US Dollar, Millions}

\begin{tabular}{|c|c|c|}
\hline & Inward FDI from & Outward FDI to \\
\cline { 2 - 3 } & United States & United States \\
\hline 2015 & 1578.2 & 1334.5 \\
\hline 2016 & 507.6 & 831.0 \\
\hline 2017 & 233.7 & 796.2 \\
\hline 2018 & 498.0 & 775.4 \\
\hline 2019 & 349.5 & 595.3 \\
\hline
\end{tabular}

Source: OECD, $2021^{12}$.

With regard to investment, U.S. foreign direct investment (FDI) to Turkey amounted to approximately $\$ 3.5$ billion in 2019 , with a decrease from the 2018 value of approximately $\$ 5$ billion, while FDI from Turkey to U.S. was approximately $\$ 6$ billion in 2019, again with a decrease from the 2018 value of approximately $\$ 7.8$ billion. As can be seen in Table 3, FDI between Turkey and the U.S. decreased in years, referring to a capacity below its potential as in the case of trade. Manufacturing, wholesale trade, and depository institutions constitute the main categories of U.S. foreign direct investment in Turkey ${ }^{13}$.

It can be argued that there are considerable but neglected cooperation areas such as trade and investment in Turkish-American relations. Hence, although security issues dominated bilateral relations because of strong intellectual, political and geostrategic roots (Larrabee and Lesser 2003: 163), in addition to these security issues and the relations in the political sphere, it is also this economic dimension that needs to be taken into account when considering Turkish-American relations and making policy recommendations. In fact, the relationship between economic and political domains is mutual. Just like politics, economics itself cannot give a complete picture of the dynamics behind the events. In Okyar's words: "Experience and history teach us that noneconomic factors - political, strategic, and perhaps cultural - always influence in varying degree the course of economic policy. This is illustrated by the example of Turkey, where, in addition to purely economic motives, these factors have been influential in shaping economic policies throughout the history of the Republic" (Okyar 1979: 326). Hence, a study, which does not take into consideration this mutual relationship would be incomplete. This study also aims to contribute to the literature with its emphasis on this reality and to provide the very much needed political economy approach.

\section{Conclusion}

Since 1945, Turkey's relations with the United States have been an important component of its foreign and security policy. This relationship has remained crucial for both sides for decades, and it still bears prominence. The membership of Turkey in NATO comprised comprehensive relations with the United States in political and economic spheres as well as the military ties. After WWII, the world political leaders were aware of the fact

12 See the data in <https://data.oecd.org/>, 28.10.2021.

13 See <https://ustr.gov/countries-regions/europe-middle-east/europe/turkey>, 13.09.2021. 
that national security could not be considered independent of the conditions in the world economy. In this sense, the United States made use of its unchallenged economic position in securing its strategic aims (Pollard, 1985: 289).

The two emphasis of this paper - legacy of the Truman Doctrine and the importance of political economy lessons to be learned from - become even more relevant in the light of the recent developments in Turkish-American relations. Particularly, in the wake of the uprising in Syria, two countries' relative positions and moves on the ground led to evergreater rifts in bilateral relations. Once again in the history of Turkish-American relations, security and geopolitics captured the relations. In the face of the growing security threats originating from Syria, Turkey has engaged in increased cooperation with other actors such as Russian and Iran, which has long been designated by the US as threats to the international order. Moreover, Turkey's purchases of S-400 air defence systems from Russia has further deteriorated the mutual trust between Turkey and the U.S., while the former blames the latter for supporting groups regarded as terorist organisations and the latter accuses the former for acting against American interests and Western preferences.

The significance of economic relations in Turkish-American relations, on the other hand, has once again come to the forefront following the American threats to impose sanctions on the Turkish economy unless Turkey restructures its relative positions in line with those of the U.S. While economic tools offer alternative punitive policy moves for the U.S., inclusion of economic gains as a motivation for both sides would make significant contributions to Turkish-American relations. As Alzawawy stated (2021: 25): "Turkey has been a cornerstone of the American strategy to contain Russia since the time of the famed Truman Doctrine". Since one of the main U.S. strategies during the current Joe Biden Presidency still comprises "containing Russia" (as cited in Alzawawy 2021: 25) in addition to the others, it can be claimed that legacy of the Truman Doctrine is still valid for the current Turkish-American relations.

In the past few decades, the world economy has been witnessing immense flows of financial capital, strong trading blocs have emerged, there is increase in high-technology production, and accordingly, developing countries feel the need to transfer this technology. In this sense, Turkey's relations with the United States is decisive. A self-sustained economy does not imply an economy merely depending on itself but it rather includes achieving not only self-sufficiency as a nation but it also has the aim of increasing its capacity in international trade and exchange of services and factors of production in order to integrate with the world economy (Okyar, 1979: 340). From this point of view, stakes are high for both Turkey and United States if they can enhance their economic relations. Increased economic interdependence, in turn, would foster political relations, and help the two nations overcome the choke points.

Despite the fact that the task of reviving Turkish-American relations via tools of political economy is not an easy one, there are a number of steps to be taken which can pave the way to this goal. Firstly, both parties should bear in mind that the U.S. possess the 
greatest military and economic power in the world. American military and technological myth should be regarded as a potential propeller for bilateral relations. According to the FDI statistics in Turkey, the U.S. lags behind European countries such as Germany, Austria, Belgium, Netherlands, England and Spain, making it the $10^{\text {th }}$ biggest investor in Turkey. Despite the geographical distance between two countries, bilateral trade volume can be increased. In addition, an increased flow of U.S. technology and investment into Turkey should be encouraged by both policy makers and business groups. Greater American role in Turkey's industrialisation journey would not only enhance both parties' commitment to bilateral relations but also provide a regional economic strategy for American business makers. In other words, regarding Turkey as an industrial production hub rather than a military headquarter is more likely to create a mutually-acceptable partnership. Turkish business groups have made efforts for the sake of increasing investment and trade ties between the two countries. As an example, the opening up of a representative office of TUSIAD in Washington can be given (Larrabee \& Lesser, 2003: 180). In this sense, the private sector can take a more active role in deepening economic relations in addition to the state policies implemented. On the other hand, joint ventures in terms of military technology would also revive Turkish-American military cooperation. In this regard, Turkey's bid for greater participation in international consortium for manufacturing of F-35 Joint Strike Fighter aircrafts should be supported by the U.S. Remembering Turkish appreciation of American military assistance as part of the Truman Doctrine and the contribution it made to development of Turkish-American strategic partnership, such joint ventures would be highly welcomed by Turkey that seeks to nationalise its military industry. Secondly the U.S. should seek quest for greater engagement in Turkey's efforts to achieve peaceful use of nuclear energy for the sake of its economic growth. As a net importer of energy sources, Turkey actively cooperates with Russia and Japan for the construction of nuclear energy power plants in Sinop and Mersin provinces. Increased American participation in such mega projects designed by Turkey would not only mitigate American concerns with regard to Turkey's political orientation, but also help Turkey diversify its supply sources and increase its bargaining power. Thirdly, only a few of the Americans are informed about Turkey, while the positive image of the United States is in decline in the eyes of the Turks as previously mentioned in this paper. The U.S. should bear in mind that every American policy which creates negative outcomes for Turkey consequently lead to rise of anti-Americanism in the country. However, the U.S. should also remember that in Turkey, there is no "principal antiAmericanism", which opposes American values. To put it differently, the U.S. can win hearts and minds of Turkish people as long as U.S. decision makers pay plenty of attention to Turkey's expectation and sensitivities. Increased visibility of American support to educational, scientific, cultural and social life in Turkey would be the right course of action to be taken for this purpose.

To sum up, learning from the success of the Truman Doctrine and refraining from letting its legacy choke Turkish-American relations is pivotal for the future of the two countries' bilateral relations. Besides, both parties should make efforts to inject "positive matters of cooperation" into their common agenda on every occasion. 


\section{References}

Adıvar, H. (1930), Turkey faces West, New Haven: Yale University Press.

Al-Marashi, I. (2018), The enduring legacy of Operation Desert Storm, $<$ https://www.aljazeera.com/indepth/opinion/2016/01/operation-desert-storm-25-yearsiraq-saddam-hussein-kuwait-160117064302534.html>, 27.11.2019.

Alzawawy, M.S. (2021) "What Biden May Bring to the Eastern Mediterranean Region", Insight Turkey, 23(1), 23-34.

Aras, B. \& R. Karakaya-Polat (2008), "From Conflict to Cooperation: Desecuritization of Turkey's Relations with Syria and Iran”, Security Dialogue, 39(5), 495-515.

Arısan-Eralp, N. \& S. Aydın-Düzgit \& A. Eralp \& E.F. Keyman \& Ç. Nas (2021) “Turkey-U.S. Relations in the changing transatlantic context", IPC Policy Brief.

Atmaca, A.Ö. (2011) "Yeni Dünyada Eski Oyun: Eleştirel Perspektiften Türk-Amerikan İlişkileri”, Ortadoğu Etütleri, 3(1), 157-191.

Atmaca, A.Ö. (2014) "The Geopolitical Origins of Turkish-American Relations: Revisiting the Cold War Years", All Azimuth, 3(1), 19-34.

Babacan, M. (2011), "Whither an axis shift: a perspective from Turkey's foreign trade", Insight Turkey, 13(1), 129-157.

Barkey, H.J. (2011), “Turkey and Iraq: The Making of a Partnership”, Turkish Studies, 12(4), 663674.

Beyoghlow, K.A. (2020), Turkey and the United States on the Brink: Implications for Nato and the US-Turkish Strategic and Military Partnership, Strategic Studies Institute and U.S. Army War College Press.

Bilgin, M.S. \& S. Morewood (2004), "Turkey's Reliance on Britain: British Political and Diplomatic Support for Turkey against Soviet Demands", Middle Eastern Studies, 40(2), 24-57.

Blackwill, R.D. \& J.M. Harris (2016), War by Other Means. Geoeconomics and Statecraft, Cambridge, Massachusetts London, England: The Belknap Press of Harvard University Press.

Buhari-Gulmez, D. (2020), "The resilience of the US-Turkey alliance: divergent threat perceptions and worldviews", Contemporary Politics, 26(4), 475-492.

Calabrese, J. (1998) "Turkey and Iran: Limits of a Stable Relationship", Journal of Middle Eastern Studies, 25(1), 75-94.

Civan, A. \& S. Genc \& D. Taser \& S. Atakul (2013), "The effect of new Turkish foreign policy on international trade", Insight Turkey, 15(3), 107-122.

Çalış, S. (1997), "Turkey in the International System of Western States”, Pakistan Horizon, 50(3), 75-100.

Danforth, N. (2021) “A Cool, Cautious Calm: US-Turkey Relations Six Months into the Biden Administration", Foreign Policy at Brookings.

EPDK (Republic of Turkey, Energy Market Regulatory Authority), (2019), Turkish Natural Gas Market Report.

Erhan, Ç. \& E. Sıvış (2017) "Determinants of Turkish-American Relations and Prospects for the Future", Insight Turkey, 19(1), 89-116. 
Evered, K. (2010), “The Truman Doctrine in Greece and Turkey: America's Cold War fusion of development and security", Arab World Geographer, 13, 50-65.

Flanagan, S.J. \& P.A. Wilson (2021) "Implications for the U.S.-Turkish Partnership and the U.S. Army", in: RAND Corporation, Turkey's Nationalist Discourse, Implications for the U.S.-Turkish Strategic Partnership and the U.S. Army. Santa Monica: RAND Corporation.

Gelb, L. (2010), "GDP Now Matters More Than Force: A U.S. Foreign Policy for the Age of Economic Power", Foreign Affairs, 89(6), 35-43.

Gordon, P. \& O. Taspinar (2008), Winning Turkey, Harrisonburg,Virginia: R.R. Donnelley.

Grigoriadis, I. (2010), "Friends No More? The Rise of Anti-American Nationalism in Turkey", Middle East Journal, 64(1), 51-66.

Gunter, M. (2005), “The U.S.-Turkish Alliance in Disarray”, World Affairs, 167(3), 113-123.

Isyar, Ö.G. (2005) "An Analysis of Turkish-American Relations from 1945 to 2004: Initiatives and Reactions in Turkish Foreign Policy", Alternatives: Turkish Journal of International Relations, 4(3), 21-52.

Kalyon, L. (2010) “Truman Doktrini Üzerine Bir Analiz”, Güvenlik Stratejileri Dergisi, 6(11), 7-26.

Kılıç, E. (2017), “The Political Economy of Turkey's Trade Relations: Expensive Enmities and Cheap Amities", Master's Thesis, Hacettepe University.

Kindleberger, C. (1968), "The Marshall Plan and the Cold War”, International Journal, 23(3), 369382.

Kosebalaban, H. (2011), Turkish Foreign Policy, New York: Palgrave Macmillan.

Kurç, Ç. (2017) "Between defence autarky and dependency: the dynamics of Turkish defence industrialization", Defence Studies, 17(3), 260-281.

Kutlay, M. (2011), "Economy as the 'practical hand' of 'new Turkish foreign policy': a political economy explanation", Insight Turkey, 13(1), 67-88.

Larrabee, F. \& I. Lesser (2003), "Turkey and The United States", in: Turkish Foreign Policy in an Age of Uncertainty, Santa Monica, CA; Arlington, VA; Pittsburgh, PA: RAND Corporation, 159-186.

Larrabee, F. (2010), Troubled Partnership: U.S.-Turkish Relations in an Era of Global Geopolitical Change, Santa Monica, CA; Arlington, VA; Pittsburgh, PA: RAND Corporation.

Larrabee, S.F. (2010), “Turkey's New Geopolitics”, Survival, 52(2), 157-180.

Lesser, I.O. (2006), "Turkey, the United States and the Delusion of geopolitics", Survival, 48, 83-96.

Livingston, C. (1994), “' 'One Thousand Wings': The United States Air Force Group and the American Mission for Aid to Turkey, 1947-50", Middle Eastern Studies, 30(4), 778-825.

Merrill, D. (2006), “The Truman Doctrine: Containing Communism and Modernity”, Presidential Studies Quarterly, 36(1), 27-37.

Müftüler-Bac, M. (2005), "Turkey and the United States: The Impact of the War in Iraq", International Journal, 61(1), 61-81.

Müftüler-Baç, M. (2014), "Changing Turkish foreign policy towards Iraq: New tools of engagement", Cambridge Review of International Affairs, 27(3), 538-552.

Nurgün-Koç, N., \& B. Koç. (2017) "Effects of Marshall Plan on Turkish Economy”, Sociology Study, 7(2), 83-121. 
Okyar, O. (1979), "Development Background of the Turkish Economy, 1923-1973”, International Journal of Middle East Studies, 10(3), 325- 344.

Oran, B. (2011), Turkish Foreign Policy, 1919-2006, Salt Lake City: The University of Utah Press.

Ozel, S. (2011), "Indispensable even when unreliable: An anatomy of Turkish-American relations", International Journal, 67(1), 53-64.

Öniş, Z. (2011), "Multiple faces of the 'new' Turkish foreign policy: underlying dynamics and a critique", Insight Turkey, 13(1), 47-65.

Pollard, R. (1985), "Economic Security and the Origins of the Cold War: Bretton Woods, the Marshall Plan, and American Rearmament, 1944-50", Diplomatic History, 9(3), 271-289.

RAND Corporation (2021), Turkey's Nationalist Discourse, Implications for the U.S.-Turkish Strategic Partnership and the U.S. Army, Santa Monica: RAND Corporation.

Satterthwaite, J. (1972), “The Truman Doctrine: Turkey”, The Annals of the American Academy of Political and Social Science, 401, 74-84.

Sinkaya, B. (2012), "Rationalization of Turkey-Iran Relations: Prospects and Limits", Insight Turkey, 14(2), 137-156.

Stein, A. (2011), "Resetting U.S.-Turkish Relations: Charting a New Way Forward", Journal of Strategic Security, 4(1), 1-18.

Trask, R. (1970), “The "Terrible Turk" and Turkish-American Relations in the Interwar Period”, The Historian, 33(1), 40-53.

Ülgen, S. (2021) "Redefining the U.S.-Turkey Relationship", Carnegie Endowment for International Peace Working Paper.

Ünlü-Bilgiç, T. (2015), “The Roots of Anti-Americanism in Turkey 1945-1960”, Bilig, 72, 251-280. Yilmaz, Ş. (2006), "Challenging the Stereotypes: Turkish-American Relations in the Inter-War Era", Middle Eastern Studies, 42(2), 223-237.

\section{Appendix}

Table: A.1

Turkey's Imports from United States of America ${ }^{14}$

\begin{tabular}{|c|c|c|c|c|}
\hline $\begin{array}{l}\text { Product } \\
\text { Code }\end{array}$ & Product Label & $\begin{array}{l}\text { Value in 2020, } \\
\text { USD thousand }\end{array}$ & $\begin{array}{l}\text { Annual growth in value } \\
\text { between } 2016-2020, \%\end{array}$ & $\begin{array}{c}\text { Share in Turkey's } \\
\text { imports, \% }\end{array}$ \\
\hline 88 & Aircraft, spacecraft, and parts thereof & 1903349 & 0 & 51 \\
\hline 75 & Nickel and articles thereof & 96535 & 8 & 44 \\
\hline '81 & Other base metals; cermets; articles thereof & 92440 & 16 & 42 \\
\hline '08 & Edible fruit and nuts; peel of citrus fruit or melons & 243144 & 15 & 27 \\
\hline '02 & Meat and edible meat offal & 17923 & & 24 \\
\hline 52 & Cotton & 592352 & 1 & 23 \\
\hline 47 & $\begin{array}{l}\text { Pulp of wood or of other fibrous cellulosic material; } \\
\text { recovered (waste and scrap) paper or ... }\end{array}$ & 156010 & 2 & 17 \\
\hline '90 & $\begin{array}{l}\text { Optical, photographic, cinematographic, measuring, } \\
\text { checking, precision, medical or surgical ... }\end{array}$ & 648453 & -1 & 14 \\
\hline
\end{tabular}

14 For the complete data set see:

$<$ https://www.trademap.org/Bilateral.aspx? nvpm $=1 \% 7 c 792 \% 7 c \% 7 c 842 \% 7 c \% 7 c$ TOTAL\% $\%$ c\% $\%$ c\% $\%$ c2\% $\%$ c1

$\% 7 c 1 \% 7 c 1 \% 7 c 1 \% 7 c \% 7 c 1 \% 7 c 1 \% 7 c>, 01.09 .2021$. 
K1lı̧, E.C. \& I. Özer-İmer (2021), "Legacy of the Truman Doctrine on Turkish-American

Relations: A Political Economy Perspective”, Sosyoekonomi, 29(50), 109-130.

\begin{tabular}{|c|c|c|c|c|}
\hline 37 & Photographic or cinematographic goods & 15003 & 12 & 13 \\
\hline '36 & $\begin{array}{l}\text { Explosives; pyrotechnic products; matches; } \\
\text { pyrophoric alloys; certain combustible preparations }\end{array}$ & 5658 & 33 & 13 \\
\hline 22 & Beverages, spirits and vinegar & 57144 & 25 & 12 \\
\hline 30 & Pharmaceutical products & 536507 & 0 & 11 \\
\hline '23 & $\begin{array}{l}\text { Residues and waste from the food industries; } \\
\text { prepared animal fodder }\end{array}$ & 179386 & -13 & 10 \\
\hline '05 & Products of animal origin, not elsewhere specified or included & 5249 & -10 & 10 \\
\hline '27 & $\begin{array}{l}\text { Mineral fuels, mineral oils and products of their distillation; } \\
\text { bituminous substances; mineral ... }\end{array}$ & 1007407 & 11 & 9 \\
\hline 29 & Organic chemicals & 497248 & 22 & 9 \\
\hline 44 & Wood and articles of wood; wood charcoal & 39414 & -30 & 9 \\
\hline 72 & Iron and steel & 1262238 & 11 & 8 \\
\hline '97 & Works of art, collectors' pieces and antiques & 586 & -52 & 8 \\
\hline
\end{tabular}

Source: ITC, Trade Map, 2021.

Table: A.2

Turkey's Exports to United States of America ${ }^{15}$

\begin{tabular}{|c|c|c|c|c|}
\hline & & $\begin{array}{l}\text { Value in 2020, } \\
\text { USD thousand }\end{array}$ & $\begin{array}{l}\text { Annual growth in value } \\
\text { between } 2016-2020, \%\end{array}$ & $\begin{array}{l}\text { Share in Turkey's } \\
\text { exports, \% }\end{array}$ \\
\hline '93 & Arms and ammunition; parts and accessories thereof & 332252 & 28 & 65 \\
\hline 57 & Carpets and other textile floor coverings & 942942 & 28 & 36 \\
\hline 68 & Articles of stone, plaster, cement, asbestos, mica or similar materials & 382094 & 5 & 26 \\
\hline 88 & Aircraft, spacecraft, and parts thereof & 238118 & -9 & 26 \\
\hline '81 & Other base metals; cermets; articles thereof & 38102 & 142 & 26 \\
\hline '09 & Coffee, tea, maté and spices & 58834 & 23 & 23 \\
\hline 80 & Tin and articles thereof & 1455 & 124 & 20 \\
\hline '17 & Sugars and sugar confectionery & 105996 & 8 & 16 \\
\hline '71 & $\begin{array}{l}\text { Natural or cultured pearls, precious or semi-precious stones, } \\
\text { precious metals, metals clad ... }\end{array}$ & 962247 & 38 & 14 \\
\hline '69 & Ceramic products & 156351 & 19 & 13 \\
\hline 24 & Tobacco and manufactured tobacco substitutes & 111154 & -13 & 12 \\
\hline 91 & Clocks and watches and parts thereof & 4027 & 32 & 12 \\
\hline '63 & $\begin{array}{l}\text { Other made-up textile articles; sets; worn clothing and } \\
\text { worn textile articles; rags }\end{array}$ & 281599 & 3 & 11 \\
\hline '56 & $\begin{array}{l}\text { Wadding, felt and nonwovens; special yarns; twine, cordage, } \\
\text { ropes and cables and articles thereof }\end{array}$ & 103297 & 18 & 11 \\
\hline '12 & $\begin{array}{l}\text { Oil seeds and oleaginous fruits; miscellaneous grains, seeds and fruit; } \\
\text { industrial or medicinal ... }\end{array}$ & 45548 & -14 & 11 \\
\hline 25 & Salt; sulphur; earths and stone; plastering materials, lime and cement & 270182 & 24 & 10 \\
\hline 20 & Preparations of vegetables, fruit, nuts or other parts of plants & 246695 & 20 & 10 \\
\hline 55 & Man-made staple fibres & 88709 & 3 & 10 \\
\hline '46 & $\begin{array}{l}\text { Manufactures of straw, of esparto or of other plaiting materials; } \\
\text { basketware and wickerwork }\end{array}$ & 201 & 179 & 10 \\
\hline '34 & $\begin{array}{l}\text { Soap, organic surface-active agents, washing preparations, } \\
\text { lubricating preparations, artificial ... }\end{array}$ & 100672 & 82 & 9 \\
\hline 33 & Essential oils and resinoids; perfumery, cosmetic or toilet preparations & 82269 & 77 & 9 \\
\hline '36 & $\begin{array}{l}\text { Explosives; pyrotechnic products; matches; pyrophoric alloys; } \\
\text { certain combustible preparations }\end{array}$ & 2039 & 56 & 9 \\
\hline 97 & Works of art, collectors' pieces and antiques & 957 & -3 & 9 \\
\hline 92 & Musical instruments; parts and accessories of such articles & 955 & 4 & 9 \\
\hline
\end{tabular}

Source: ITC, Trade Map, 2021.

15 For the complete data set see:

$<$ https://www.trademap.org/Bilateral.asp $x$ ?nvm $=1 \% 7 c 792 \% 7 c \% 7 c 842 \% 7 c \% 7 c$ TOTAL\% $\%$ c\% $\%$ c\% $\%$ c2\%7c1

$\% 7 c 1 \% 7 c 2 \% 7 c 1 \% 7 c \% 7 c 1 \% 7 c 1 \% 7 c 1 \% 7 c 1>, 01.09 .2021$. 